\begin{tabular}{l|l} 
& $\begin{array}{l}\text { Eastern } \\
\text { European } \\
\text { Countryside }\end{array}$ \\
\hline DO.1515/eec-2015-0011 & $21^{\prime} 2015$
\end{tabular}

Elwira Piszczek

\title{
Social Research Studies of the Village in the Historical Perspective: the Family Farm Formerly and Now
}

Vonderach, G. (2015), Die Erforschung ländlicher Lebenswelten. Streifzüge durch Geschichte der ländlichen Sozialforschung [Research studies of the rural worlds of the life. The journeys through the history of social researches of the rusticity], Aachen: Shaker Verlag.

Bohler, K. F., A. Sterbling, and G. Vonderach, eds. (2014), Der bäuerliche Familienbetrieb [The family farms], Aachen: Shaker Verlag.

We would like to present two publications concerning rural areas in the present text, which has come out under the already known to the readers of Eastern European Countryside series 'Buchreihe Land-Berichte' name.

1 The series Buchreihe Land-Berichte shows the subject matter related to rural areas (above all, it focuses on Germany, Central and Eastern Europe and Southern Europe). Under its name has come out 10 volumes up till now (we bring nearer the last two in the present text), from which were discussed in Eastern European Countryside:

Piszczek E. (2011), 'The Tradition and Modernity in the South-Eastern Europe - the Balkan Countries' search for their own way of Social Development in a Modern, United Europe' (Sterbling, A. (2010),. Entwicklungsverläufe, Lebenswelten und Migrationsprozesse. Studien zu ländlichen Fragen Südosteuropas, Aachen: Shaker Verlag), in: Eastern European Countryside, vol. 17, [DOI: 10.2478/v10130-011-0009-9].

Piszczek E. (2013), 'The Life and work in the rural Germany' (Vonderach, G. (2012) Arbeitsmarkt-Akteure im historischen Wandel. Beiträge zur Entwicklung der Arbeitsmarktforschung, Vonderach, G. (ed.), Aachen: Shaker Verlag; Begegnung mit historischen Arbeitswelten. Ausgewählte ländliche Museen mit Schwerpunkten vergangener 
First of them is the volume edited by Karl Frierdrich Bohler, Anton Sterbling and Gedr Vonderach entitled 'Der Bäuerliche Familienbetrieb' ['The family farms'] (volume 9). The second book by Gerd Vonderach entitled 'Die Erforschung ländlicher Lebenswelten. Streifzüge durch Geschichte der ländlichen Sozialforschung' is the tenth volume of the series ['Research studies of the rural worlds of the life. The journeys through the history of social researches of the rusticity'].

We propose one to start discussing the both books from the last volume- the tenth one. It is dedicated to basic, general issues related to the presentation of the development of researches on the village and rusticity; and thus, it indirectly shows the development of the sociology of the village as a scientific (sub)discipline. We present the subject matter of the ninth volume in this context, in which the authors display more detailed questions concerning the farming families.

Gerd Vonderach both in his many other previous publications and in mentioned here book 'Die Erforschung ländlicher Lebenswelten... consequently brings the readers closer to the history of the development of researches on the rusticity. This time, Vonderach takes up as his task the journey through the paths of the development of social researches on rusticity from their beginnings to the present day on the basis of the history of the selected countries, limited to the countries of Central and Eastern Europe, [...] North America and Eastern Asia [..] (p. 5-6).

The sociology of the village and agriculture is one of the oldest subdisciplines of sociology (for example in Poland and Germany). The rural subject matter was explored from many years in many countries, though it was done under the name of other scientific disciplines (for instance in Switzerland, where it was rather connected with ethnology). Bringing together within one volume and presenting the rich history of researches on the village and agriculture is an extremely difficult task; especially, when a different specificity of national's sociologies of the village does not enable too many abbreviations-generalisations. However, the author is aware of these limitations; and therefore, as I suppose, just at the beginning he

regionaler Wirtschaftsweisen, Aachen: Shaker Verlag and Vonderach, G. (2013), LandLeben. Beiträge zur Entwiclung ländlicher Lebenswelten, Aachen: Shaker Verlag), in: Eastern European Countryside, vol. 19. [DOI : 10.2478/eec-2013-0011] 
clearly emphasises that some issues will be presented in short, in a limited way, outlined(p. 5, 6).

Essentially, this book consists of three parts. In the first part, Vonderach describes in a short manner the theoretical background (of the history of social development), on which he depicts the selected issues of the rural development (broken down into the so called agrarian and postagrarian period). It is worth indicating, in the view of many discussions on the appropriate definition of rusticity that which is (not) the village, the understanding of 'the village' which the author recognises as the most justifiable. In his considerations on 'the village' one can speak sensibly only relating on the one hand to the nature (nature), and on the other hand to the urban areas (p. 9). The conceptions of the development proposed by the Dutch explorer Fred Spier, the historian Rolf Peter Sieferlego and Emile Durkheim (referring to the social evolution of 'the systems': Spier's 'regulatory systems', Sieferlegos 'regimes', Durkheim's primary and developed society) become the mentioned theoretical background of Vonderach's considerations. On the basis of the transformation- evolution of such systems in the history of societies, the author enumerates and briefly characterizes its particular phases since the Ice Age, indicating the ways of harnessing the nature by a human (from the beginnings of cultivation of crops, animal breeding to the contemporary phenomena connected with mechanisation, chemicals in farming etc.) and organisation of social groups (including the organisation in the sense of space- villages, towns). Out of observations concerning the development of rural areas currently, the development characterised by the decline of the number of farms and the change of the function of the rural areas ( from that geared to the production of food to the housing, recreational and social function and so on), noteworthy are the discussed, important from Vonderach's point of view, very dynamic processes of migration town/city-village, village-town/ city (Pendlertum). Thanks to the developed systems of communication, mobile technology etc., it is possible to more often link working in a town/ city with living in a village. These processes have influence to a large degree on how the rural areas in Germany and other countries in Europe are developing currently.

The next part of Vonderach's work is the presentation of the development of researches on rusticity, systematised by not the subject matter of the researches but with regard to 'nationality' of the selected sociologies of 
the village (three consecutive chapters: 'Kurzer Überblick zur weltweiten Entwicklung der ländlichen Sozialforschung, Die Entwicklung der ländlichen Sozialforschung in Deutschland and Die ländliche Sozialforschung in einigen mittel - und osteuropäischen Länder'). The most developed excerpts discussing the development of the sociology of the village concern Germany and Poland, he pays less attention to some other countries (for instance Hungary). In spite of the subject matter being present in many publications both German and English ones, Vonderach shows many details worth familiarizing. We will start their short discussion not chronologically from Germany, the more developed part.

The author starts the presentation of the development of German sociology of the village from the Empire period, taking up the subject matter of conducted already in the first half of the nineteenth century surveys of the village and agriculture (for example the first surveys carried out were commissioned by Königlichen Landes-Oekonomie-Collegiums already in 1848). Vonderach describes this period, of numerous and interesting studies, as momentous, significant in the development of researches on rusticity; as opposed to, the next discussed phase - the Weimar Republic, described as the time not worth any special attention (p. 43). As the author observes, despite starting then the process of institutionalisation of sociology at the universities and research institutions, with existing then many problems connected with agriculture, issues relating to the problems of the village and agriculture did not absorb scientists' attention. The stimulation of researches on rusticity is characterised by the next discussed period - the Nazism times. The ideology 'Blut und Boden', mythologisation and ideologization of the peasants (the breadwinners of the nation), work on the farm promotes further institutionalization of the sociology of the village and taking up more researches. Vonderach indicates the fact that the numerous group of scientists- active in the Nazism period, was also still present at the scene of the scientific researches on the village after the war. Vonderach pays relatively much attention to the next phase, starting in the fifties and sixties in RFN, bringing and presenting essential conclusions from the significant researches of the period, to which the so called 'Darmstadt-Studien' project has become the starting and reference point. Also in the human 'dimension' it is a time of the development of the sociology of the village - the time of the first professorates related to this subject matter (Helmuth Woll, Urlich Planck, Herbert Kötter and others). The institutionalization of the sociology 
of the village also takes place in NRD; unfortunately, as the author observes, many studies were only partly published (the information were decided by the ruling party).

The next phase of the development of the sociology of the village in the Western Germany distinguished by the author is the period from the end of seventies, which can be shortly characterised as the time of the intensified field studies on the basis of more and more developed research methods, both typically statistic (standardisation) and quality -observations, examination of documents, the extensive interviews the so called pluralistic approach in the dimension of the applied research methods in the field studies - methodenpluralistisches Vorgehen der Feldforschung (p. 55). It is also the period of further institutionalisation of the sociology of the village, discussed also in relation to the areas of the Western Germany after 1989, which promoted the development of the research on rusticity, also in the meaning of some sort of interdisciplinarity. Vonderach highlights the significance of the interesting studies carried out by historians, geographers, ethnologists etc. The period after the reunification of Germany is also the time of the New problems on the rural areas, which outlined completely new research fields and in some sense also implied the comparative formula of the researches (given rural areas of RFN and NRD).

In the chapter preceding the presentation of the development of the researches on rusticity in Germany (indicated above), the author has started the description of the researches on the rural and agricultural subject matter in the other selected countries. After its presentation in relation to America and some words on Latin America, Vonderach moves to the countries of Eastern Asia. It should be stressed that as much as the subject matter concerning the development of the sociology of the village (the researches on the village) in America and Europe is often present in the literature of the subject (the author himself relates to this literature in his very rich bibliography), the information concerning the Asian countries, less often appearing in studies of that type, constitute some kind of novelty and give value to the present publication. In this chapter, the author again moves from "the Asian territories” to Europe, very briefly indicating a few, in his opinion, import ant facto connected with the development of the researches on rusticity in Switzerland, Holland, France, the countries of Southern Europe and Hungary. 
These threads are continued in the next part of the work, but only in the selected countries-and in more developed form. The author pays his attention to Austria, Poland ( it is the most extensive discussion of the development of 'the national' sociology of the village, apart from the excerpt concerning Germany) and Romania.

The study of these few selected national sociologies of the village is very profound and detailed. Vonderach mentions much biographic and bibliographic data, dates and institutions, describing the evolution of this subdiscipline of the science. For sure, many facts concerning Germany will not be a novelty to the German speaking, interested in the problem readers, as the author himself has paid attention to the history of the German sociology of the village in his many previous publications. Apart from that, this subject is exploited by other explorers (for example Bodensteadt in 2003; Beetz, Brauer and Neu in 2005 etc.). The researches on rusticity presented in the remaining discussed countries, not so often present in the Western European subject literature as we think, will be a much more novelty to the readers ${ }^{2}$.

The presented work has the historical character, which however ends up on the question about the future (the chapter: 'Gedankenskizzen zu einigen zukunftorientierten Forschungsfeldern der Landsoziologie'). The author asks himself the question not for the first time, and the question is: gibt es für Landsoziologen keine interessanten Themen mehr? [Do the sociologists of the village have yet some other interesting subjects to explore?] (for example Vonderach in 2013, Land-Leben. Beiträge zur Entwiclung ländlicher Lebenswelten).

In reference to the contents of the book, one can paraphrase it by asking if apart from the descriptions and conclusions of what was, the sociology of the village has something more to offer as the scientific discipline? In this light, the other question emerges- about the future of the rural areas and the population living there. According to Vonderach this kind of the future - abounding in Worth exploration research subjects exists. As such

${ }^{2}$ Despite the fact that on the German publishing market the subject matter is often present, it seems that the basic source of the information on the sociology of the village (the researches on the rusticity) in countries other than German speaking, remains mainly the series Buchreihe Land-Berichte and co-existing magazine Land-Berichte. Sozialwissenschaftliches Journal . 
is distinguished, in the first place, agriculture(but it indicates not on the statistically analysed changes, but on the quality and biographic analysis of the perspectives of the family farms: these conventional as well as more and more "trendy" currently bio and eco farms). Apart from that, the natural and cultural landscape, the relation human-nature, is becoming the more and more significant research thread in the sociology of the village. At the junction of nature-agriculture we also have the next research field: the sociology of relation man-animal (wild, domestic).

Vonderach indicates also one another field of the researches, which will be significant to the sociology of the village in the near future. It is connected with the mobility of the people, the very broad understanding of the migrations, not only as the mobility town/city-village, village-town/city (for work, in order to settle), but also as the migrations South Europe- North Europe, east-west, and even in the cultural/religion sense the islamists to the German territory etc. The new map of settlements, regions is created, which relations 'between' as well as processes 'inside' constitute the new research challenge.

The second of mentioned here books - although published a year earlier than the above discussed one, is some sort of reply to the challenge of Vonderach, relating to the future, significant research themes of the sociology of the village. It is the edited book, consisting of the six works devoted to the farms. Let us remind that in the tenth volume of the series 'Buchreihe', Vonderach appealed for the quality, biographic methodological perspective, and here we have the reflection of it; as, the majority of the texts present the results of the researches of the concrete farming families. The exception is the last chapter Andrzej Kaleta, in which the analysis of the farming families is presented on the basis of the statistic data ('Zum Wandel in bäuerlichen Familien und Familienbetrieben in Polen'). The tradition of writing the review is presenting, of course in the shortened version, (the selected) contents of the described publication. In this case it would be connected with the presentation of the six studies of the volume- which would be copying of the work done by one of the coeditors of the volume Karl Friedrich Bohler. In the very clearly written 'Introduction' ('Einleitung'), the author apart from the presentation of the main threads of the book, presents generalisations, he makes types and concludes on the condition of the agricultural farms. We will only mention some of the conclusions, and in their view, presenting shortly the more 
important conclusions, we will try to display some generalisations coming from the conclusion of that what is common- this which connects all the articles. Coming back to 'The Introduction' by Bohler, who is the common characteristic of the remaining texts, it is worth noticing that the words describing the general condition of the agriculture and family farms in Germany, in Germany in the last century the agriculture as one of the sectors of economy has lost its high status even in the rural regions, and agricultural families are starting to be similar to the urban model of a small nuclear family (p. 7). In relation to these kind of changes Bohler has distinguished five main types of management in agriculture:

- with the additional income from the outside, and also "the hobby of the farm"

- the so called one-person households, which give spouses, partners new, additional possibilities of obtaining income apart from the agriculture

- the companies, in which self-reliant families are focused on the contemporary model of the division of the work

- ecological agriculture, bio-farms, based on more traditional, peasant's model of management (for example closed circle in the farm).

The author of course realises that these are only the types supporting the analysis and the social reality abounds in the examples of the farms far from the assumed theoretical models.

The illustration of these types indicated by Bohler and their evolutions are the family farms presented in the next chapters of the work. What they have in common?

The text by Vonderach ('Zur Entwicklung bäuerlicher Familienbetriebe in einer Grünlandregion') concerns mainly the example of the farms from the typical rural, the so called green region of Germany - Wesermarch, where the basic form of the management is dairy farming. And although the mentioned by the author data show a considerable fall in the number of such farms (from 6846 in 1932 to 569 in 2013), we also deal here with the considerable growth of the number of cows in the farm (from 5,3 in 1932 to even 82,6 in 2013). The similar observations are described in the next text by Karin Jürgens ('Milchbauern und ihre Wirtschaftsstile'), who writes about more general data accessible in w Statistical Yearbooks of Germany. In 1949 there were 1,54 millions of the farms oriented on the dairy farming (from 
which up to the million had less than three cows), whereas in 2010 there were only 90 thousands of such farms (including 66 thousands specializing only in dairy farming). Both authors are focused on the quality method (the interview with the representatives of the farms), they presented these kind of data not by accident; thus, they are the illustration of the trends in the development of the agriculture (specialisation, technicisation, intensification of the production etc.). The word trend has here a neutral character, is in some sense 'dehumanized'. There are the individual fates of the hosts hidden behind this Word, the histories of their dealing with the changing reality and the trials of the survival. Both of these texts present using concrete examples the strategies of handling with the changes, balancing between the tradition and modernity, between the former, peasant's way of management and the modern requirements of the economy (the gain), and also between the past lifestyles of the rural families and current ones ( for instance the problems with heritage-the lack of heir).

The mentioned problems are discussed also in the next texts. Rita Garstenauer i Sophie Tod are looking closer at the strategies of the survival of two small family farms in Lower Austria ('Ideal und Pragmatik: Resilienzstrategien zweier Kleinbetriebe in Niederösterreich'). They are looking for the answer to the question How can the farms which have no optima conditions for activity survive? In relation to the externally controlled, imposed "policies” of reformation of the village and agriculture (at the level of the country or UE), in which the hosts have to find themselves. The authors present the strategies of resilience on the examples of two interesting families, the first runs the so called hobby-farm, the second practises the winegrowing and animal breeding. What connects their analysis with the other texts is also the quality method - the extensive interviews (carried out in 2010 - 2011). The The mobility of activities oriented on the multisourcing of the income and cooperation within the family has enabled the survival of the farms.

In the study of the two examples of the farms (from USA and German speaking country) Bruno Hilderbrandt also looks for the answer to the question: what causes that the farming families can survive in the conditions of the crisis, not understood only as hardships of the economic nature but also as the problems with for example the succession in the farm ('Die Persistenz familienbetrieblicher Lebensformen'). Habitus is here used as the theoretical conception, and the agricultural habitus is presented as full 
of contradictions between what is traditional and what is modern, between the national and affective. Considerations concerning the survival of the agricultural traditions and the continuation (succession) are presented also in the next text. This time the breaking of the tradition of management could be connected with the process of collectivisation of the agriculture in $\mathrm{NRD}$. The problem is discussed on the example of the one family managing in the western part of the biggest island of Germany - Rugia. It has turned out however, that even in such difficult conditions (forced collectivisation), the keeping of the traditional peasant's habitus was possible, some "private" managing and handing down the traditional values to the young generation, who in already new conditions (after the reunification of Germany) has rebuilt the farm in its former form.

By generalizing the conclusions concerning the problems with the succession, one can say that the pressure is put not only under the parents , but also the older hosts, to whom the succession of the farm is a very difficult step. Hilderbrant mentions even the tears and the sadness of the host visible during one of the interviews, when after the question about saying goodbye to active management "[...] in this place there was the silence in the room. The sorrow was clearly visible (p. 91). It is also a difficult decision for the successors, who are often ,too well-educated” to think about taking not always enough profitable farms and having already other perspectives of life in the modern society. In majority of the cases however, these histories have happy endings, which can be connected with something not completely named (although the sociology tries to capture this phenomenon, giving it the name of ethos, the peasant's habitus). I will use the citation of the speech of one of the examined farmers, which will maybe the best illustrate the situation: the agriculture is in our blood (p. 87).

The last text by Andrzej Kaleta, despite the fact that, in contrary to other Texas consists the statistic data (not quality), constitutes the best summary of the whole of the book. The author makes use of the statistic data to illustrate the processes, which were discussed also in the previous parts of the work and although they only concerned Poland, they very well correspond with the facts presented in the other articles. The most import ant from the point of view of the whole publication seems to be the following phenomena: deagrarisation, the separation of the farms from the farming families and the change of the conditions, the quality of the 
village life (including not only the farming families). The influence of all these processes on the condition and the strategies of survival applied in the farming families can be examined by analysis of the description of the farming families presented by the other remaining authors.

Summing up all the texts from the book 'Der Bäuerliche Famielienbetriebe', we would say that, on the basis of the quality data the conversations with the families, supported also by the statistics, the authors tried to find the answer to the question about the endurance of the family farms in the face of various types of contemporary challenges and crises. Analysing the various scenarios of the hosts' activities presented by the authors, we can claim that in such farms or the rural companies lies the enormous potential, thanks to which they are still the Basic form of the economic activity of the inhabitants of the village, although the character of the run activity is often far from the traditional- the peasant's model of the management ( mentioned in the texts processes of diversification of the income, the modern division of the work etc.). It also shows, that on the rural areas we deal with many social phenomena(migration, deagrarisation, change of the lifestyles, demographic changes, change of the function of the rural areas from oriented on the production of food to connected with leisure, settlement, social policy etc.), which observation and analysis can make a impact on the social theory. The very different question is this, which Vonderach asks in 'Die Erforschung ländlicher Lebenswelten...', about the best method of the examination of the phenomena taking place in the village, about if and how will the historical perspective help in better understanding and about that whether the individual/singled out subdiscipline of the science, as is the sociology of the village and agriculture is needed to achieve it.

Taking into account the two publications, we would say, that the pluralistic approach to the research methods, actively using the current achievement of the sociology of the village and ma king use of the achievements of other sciences, (ethnology, history, geography, economics etc.) will surely legitimize the further existence of the sociology of the village, in front of which appears new research perspectives. The mentioned already in the present text issues indicated by Vonderach belong to them: the evolution of the family farms, relation human-Nature (including also changes in the relation human-animal) or migration in 'the local' dimension town/cityvillage, village-town/city as well as in the global dimension: 'of cultures', 
'religions', which more and more influence on the rural areas. One can add to these issues also other, mentioned in the German subject literature as for instance the global problems of feeding the societies, or the management of the common resources: earth, sources of water, air. There are not the technical solutions behind these problems, but issues of political and social nature, which can be successfully analysed exactly by the sociology. (Ziche 2005: 120).

\section{References}

Bodenstedt, A. (2003), Agrar-Kultur-Soziologie [The sociology of the agriculture and culture], Gießen.

Beetz, S., K. Brauer, and C Neu (eds) (2005), Handwörterbuch zur ländlichen Gesellschaft in Deutschland [The handy dictionary of the village society in Germany], Wiesbaden.

Ziche, J., 'Land und Agrarsoziologie nach 1945' ['The sociology of the village ang agriculture after 1945'], in: Handwörterbuch zur ländlichen Gesellschaft in Deutschland [The handy dictionary of the village society in Germany], Wiesbaden. 